primary school students in the lessons "I am in the world"]. Current issues of preschool and primary education: a collection of scientific papers. Zhytomyr, pp. 134-141. [in Ukrainian].

9. Pidkasistyiy, P. I. (1972). Samostoyatelnaya deyatelnost uchaschihsya: Didakticheskiy analiz protsessa i strukturyi vosproizvedeniya i tvorchestva [Independent activity of students: Didactic analysis of the process and structure of reproduction and creativity]. Moscow, 183 p. [in Russian].
10. Savchenko, O. Ya. (1998). Umii vchytysia: navchalnyi posibnyk [Be able to learn: a textbook]. Kyiv, 192 p. [in Ukrainian].

11. Savchyn, M. V. (2007). Pedahohichna psykholohiia [Pedagogical psychology]. Kyiv, 424 p. [in Ukrainian].

12.Ushynskyi, K. D. (1974). Izbrannye pedahohycheskie sochynenyia [Selected pedagogical works]. Moskva, 1024 p. [in Russian].

Стаття надійшла до редакції 07.10.2021

УДК 94(477.8):355“1944”

DOI:

Микола Галів, доктор педагогічних наук, доцент кафедри історії України Дрогобииького державного педагогічного університету імені Івана Франка

Олександра Свйонтик, кандидат педагогічних наук, доиент кафедри загальної педагогіки та дошкільної освіти Дрогобииького державного педагогічного університету імені Івана Франка Мирослав Ющишин, здобувач другого (магістерського) рівня вищої освіти Дрогобицького державного педагогічного університету імені Івана Франка

\title{
ОСВІТНІЙ ПРОЦЕС У ЛЬВІВСЬКОМУ ДЕРЖАВНОМУ ПЕДАГОГІЧНОМУ ІНСТИТУТІ (1944-1953): ОРГАНІЗАЦІЙНІ ТА ЗМІСТОВІ АСПЕКТИ
}

У статті представлено результати дослідження організаційних $і$ змістових аспектів освітньӧ̈ діяльності Львівського державного педагогічного інституту (далі - ЛДПІ) у 1944-1953 рр. Під час дослідження застосовувалися наукові методи: історико-гентичний, проблемно-хронологічний, історикотипологічний, історико-системний, аналізу й синтезу. Проаналізовано такі аспекти організації освітнього прочесу в ЛДПІ: графіки і змістові особливості навчання, студентська самостійна робота, педагогічна практика, виховання студентів. В інституті готували вчителів мови ілітератури (украйнської та російської), історії, фізики, математики, природничих дисииплін. Встановлено, щуо графіки навчального процесу, починаючи з 1944-1945 н.р. переважно не виконувалися. Значною проблемою до кіния 1940-х рр. в роботі всіх факультетів інститут була повна або часткова відсутність нових програм навчальних дисииплін, недостатнє забезпечення підручниками.

Ключові слова: освітній процес; вищза педагогічна освіта; Львівський державний педагогічний інститут; повсякдення; педагогічна практика.

Jim. 16.

Mykola Haliv, Doctor of Sciences (Pedagogy), Associate Professor of the History of Ukraine Department, Drohobych Ivan Franko State Pedagogical University

Oleksandra Sviontyk, Ph.D. (Pedagogy), Associate Professor of the General Pedagogy and Preschool Education Department, Drohobych Ivan Franko State Pedagogical University Myroslav Yushchyshyn, Masterjs Student, Drohobych Ivan Franko State Pedagogical University

\section{EDUCATIONAL PROCESS IN LVIV STATE PEDAGOGICAL INSTITUTE (1944-1953): ORGANIZATIONALAND CONTENT ASPECTS}

The article presents the results of research of organizational and contents aspects of educational activity of Lviv State Pedagogical Institute (hereinafter - LSPI) in 1944-1953. During the research scientific methods were used: historical-genetic, problem-chronological, historical-typological, historical-systemic, analysis and synthesis. The following aspects of the organization of the educational process in LDPI are analyzed: graphics and semantic features of training, independent training of students, pedagogical practice, ideological training of students. The institute trained teachers of language and literature (Ukrainian and Russian), history, physics, mathematics, and natural sciences. It is established that the educational process schedules, starting from 1944-1945 academic year, 


\section{ОСВІТНІЙ ПРОЦЕС У ЛЬВІВСЬКОМУ ДЕРЖАВНОМУ ПЕДАГОГІЧНОМУ ІНСТИТУТІ (1944-1953): ОРГАНІЗАЦЙННТАЗМІСТОВІ АСПЕКТИ}

mostly not performed. A significant problem until the end of the 1940's in the work of all faculties of the LDPI was the complete or partial absence of new programs of academic disciplines, insufficient provision of textbooks. The content of educational work was influenced by ideological campaigns that took place in the USSR ("Zhdanovshchina"), the ideological popularization of Stalinjs "linguistic works", and I. Pavlovjs reflexological theory. It was investigated that the LDPI sought to control the independent training of students. Pedagogical practice took place mainly in schools of Lviv. Since the late 1940s, the directorate of the institute has required students to conduct classes and conduct ideological training of school pupils during pedagogical practice. Many LDPI students received high marks for their pedagogical practice, but there were cases when some students psychologically and methodically were not ready to work at school. Ideological training at the LDPI was aimed at the communist indoctrination of students. It covered various forms: lectures, excursions and meetings with famous Soviet figures, etc. Communist teachers have been attached to student groups since 1950 in order to exercise ideological influence and control (even monitor) students.

Keywords: educational process; higher pedagogical education; Lviv State Pedagogical Institute; everyday life; pedagogical practice.

Постановка проблеми. Одним із напрямів розвитку сучасної історико-педагогічної науки $\epsilon$ так звана “історія інституцій”. Вона передбачає вивчення минулого певних установ, організацій, структур, зокрема і закладів освіти. Основними аспектами, які беруться до уваги науковцями при вивченні історії певної інституції, $є$ формування їі структури, завдань, змісту діяльності, кадрового наповнення, матеріального забезпечення тощо. У контексті дослідження минувшини закладів вищої освіти України важливе значення має опрацювання матеріалів і написання історії тих вишів, які вже не функціонують. Серед таких закладів був і Львівський державний педагогічний інститут, відкритий у 1940 р. Він проіснував майже 20 років (за винятком років німецької окупації), але у 1960 р. його було переведено до Дрогобича і приєднано до Дрогобицького державного педагогічного інституту імені Івана Франка.

Аналіз останніх досліджень. Діяльність Львівського педагогічного інституту почати згадується в узагальнювальних працях з історії вищої освіти України загалом, і вищої педагогічної освіти зокрема. Серед них виділимо колективну працю "Вища школа Української РСР за 50 років" [1]; монографії I. Кошарного [11], В. Майбороди [14], О. Глузмана [2], Л. Прокопів [15], О. Лукјяненка [13]; дисертації Н. Головка [3], Т. Кобзарєвої [10], О. Сергійчука [16]. Однак синтезованого дослідження як історії Львівського педагогічного інституту загалом, так і окремих аспектів його діяльності (у тому числі освітньої) наразі не проводилося.

Мета статті - дослідити організаційні та змістові аспекти освітньої діяльності Львівського державного педагогічного інституту у 1944-1953 pp.

Виклад основного матеріалу. Львівський державний педагогічний інститут (далі - ЛДПІ) разом $з$ Львівським державним учительським інститутом (далі - ЛДУІ) було організовано радянськими владними органами впродовж першої половини 1940 р. Вони розміщувалися в одному приміщенні і керувалися спільною адміністрацією. Навіть кафедри для педагогічного і учительського вишів були спільними. Свою освітню діяльність обидва заклади розпочали 2 вересня 1940 р. [4, 2зв]. У роки німецької окупації навчальний процес в ЛДПІ та ЛДУІ, звісно, не проводився. Ухвалою РНК УРСР 20 серпня 1944 р., після трирічної перерви ЛДПІ відновив свою діяльність у складі 4 факультетів - мовно-літературного (українське, російське та польське відділення), історичного, фізико-математичного та природничого. Учительський інститут мав три факультети: мовно-літературного (українське, російське та польське відділення), історичного та фізикоматематичного [5, 1]. У довідці Львівського обкому КП(б)У від 5.10.1941 р. педагогічний та учительський інститути згадуються як одні з семи вишів Львова, які на той час відновили діяльність [12, 219-220]. Директором ЛДПІ й одночасно ЛДУІ став професор С. Смолінський $[5,29 ; 6,19]$. 31950 р. цю посаду займав Г. Ломов $[8,44]$.

Заняття на всіх курсах ЛДПІ почалися 16 жовтня 1944 р., лише фізико-математичний факультет ЛДУІ розпочав свою роботу 1 жовтня того ж року. У 1944-1945 н.р. в педінституті навчалися такі курси: мовно-літературний факультет - I та III курси українського відділу, I, II та III курси російського відділу і I курс польського відділу, історичний факультет - I, II та III курси, фізико-математичний факультет - I та II курси, природничий факультет - I курс. В ЛДУІ навчалися: на мовно-літературному факультеті - I та II курси українського відділу, I курс російського відділу; на історичному факультеті - I курс; на фізико-математичному факультеті - II курс [5, 1].

Аналізуючи організацію освітнього процесу в ЛДПІ, зупинимося на таких його аспектах: графіки і змістові особливості навчання, студентська самостійна робота, педагогічна практика, виховання студентів. 


\section{ОСВІТНІЙ ПРОЦЕС У ЛЬВІВСЬКОМУ ДЕРЖАВНОМУ ПЕДАГОГІЧНОМУ ІНСТИТУТІ (1944-1953):}

ОРГАНІЗАЦЙНІ ТА ЗМІСТОВІ АСПЕКТИ

\begin{abstract}
Графіки і змістові особливості навчання. Встановлений на початку 1944-1945 н.р. графік занять не виконувався, не було стабільного розкладу занять, деякі дисципліни в ЛДПІ викладалися протягом одного семестру замість двох. Перед початком другого семестру на всіх факультетах було запроваджено єдину форму планування і обліку праці - графіки навчального процесу за курсами і факультетами, облік виконання робочих планів викладачів, облік виконання планів на факультетах, облік виконання індивідуальних академічного навантаження, облік консультаційної роботи. Навчальні плани для перших курсів були стабільними, для других i третіх курсів укладено перехідні навчальні плани 3 урахуванням трирічної перерви у навчанні. Загалом навчальні плани в ЛДПІ були виконані на $99 \%$, чого вдалося досягти шляхом впровадження 42-годинного робочого тижня на більшій частині курсів у другому семестрі 19441945 н.p. $[5,4]$.
\end{abstract}

На той час значною перешкодою в роботі на всіх факультетах була відсутність програм навчальних дисциплін. Переважно доводилось користуватися програмами, виданими до 1941 р. Нову програму одержано лише 3 основ марксизму-ленінізму. Незадовільно складалася ситуація з навчальною літературою. Підручників і посібників в інститутських бібліотеці і кабінетах було недостатньо. 3 окремих дисциплін (старослов'янська мова, фольклор, західноєвропейська література, загальне мовознавство, діамат та істмат, політекономія) взагалі не було літератури, а 3 деяких дисциплін (шкільна гігієна, історія народів СРСР, психологія, історія літератури) - лише один-два підручники. Задовільною виявилася ситуація з літературою на фізико-математичному факультеті, де навчалися невелика кількість студентів і нестачі підручників не спостерігалося [5, 4-5].

У 1946-1947 н.р. спостерігалося невиконання планів на окремих курсах: на II курсі історичного факультету (план виконано на 96,7 \%), на III курсі історичного факультету (план виконано на 96,7 \%). Причина полягала у важкому і довготривалому захворюванні викладача історії СРСР, якого не було ким замінити. Програму на цих курсах недовиконано на 22 години практичних занять. На II курсі фізико-математичного факультету не виконано 52 години з теоретичної механіки, оскільки посеред навчального року звільнено в. о. професора Серкомського (Міністерство освіти УРСР не затвердило йому професорської ставки у ЛДПІ, тоді як у Львівському державному університеті він їі отримав) [6, 5-53в].
На деяких курсах ЛДПІ у зазначеному навчальному році здійснено "перевиконання" навчальних планів за рахунок додаткових годин 3 української мови (по 10 годин на кожному курсі), які були введені згідно з розпорядженням Міністерства освіти УРСР від 15.01.1947 р., а також за рахунок додаткових годин для вивчення біографії Леніна і Сталіна (по 6 годин на кожному курсі) [6, 5зв].

Не всі програми відповідали вимогам часу. Так, узагалі не було програм з української і російської літератур. Програма дисципліни “Західноєвропейська література” була видана ще в 1939 р. Щоправда, 1945 р. звилися нові програми iз педагогіки, психології, історії педагогіки, педагогічної практики, а також програми дисциплін фізико-математичного циклу. Підручниками на 1946-1947 н.р. повністю забезпечений був тільки фізико-математичний факультет. Для гуманітарних дисциплін, особливо “історичних" та “літературознавчих", в ЛДПІ усе ще не було достатньої кількості підручників. Загалом, педагогічний інститут на той час виявився лише на $50 \%$ забезпечений підручниками [6, 5зв-6]. Відзначимо, що у 1946 1947 н.р. відмінили військову підготовку, а фізичне виховання проводилося за навчальним планом 1941 р. [6, 6зв].

Аудиторні заняття в ЛДПІ впродовж 1948-949 н.р. проводилися стабільно, хоча спостерігалося відхилення від установленого графіка, особливо у другому півріччі, коли захворів завідувач кафедри російської мови доцент Старухін. Крім того, у першому півріччі не прочитано 30 годин 3 історії України через “неуважне ставлення" до своєї роботи викладачки Н. Цимбал. Для контролю за якістю викладання, лекції викладачів відвідували завідувачі кафедр та декани факультетів, стенографувалися деяких занять [7, 33в-4].

На початку 1948-1949 н.р. уведено заняття для підготовки вчителів музики і співів як додаткової професії. Заняття з сольного і хорового співу було організовано у трьох студентських групах. Водночас в ЛДПІ діяв хор та духовий оркестр. У групі підготовки вчителів співу виділявся студент Кущенко, який успішно керував змішаними та однорідними хорами [7, 43в-5].

Керівництво освітнім процесом в ЛДПІ здійснював заступник директора із навчальнонаукової роботи І.Д. Донець. Він протягом 1948 1949 н.р. відвідав 62 заняття в інституті. У цьому навчальному році широко використовували викладання окремих дисциплін шляхом проведення відкритих лекцій та практичних занять 
3 подальшим їх обговоренням. Загалом за навчальний рік проведено 62 відкритих лекції, які відвідували члени різних кафедр. Під час обговорень у протоколах фіксували висновки і пропозиції. Найкращими були визнані такі кафедри інституту: педагогіки і психології, основ марксизму-ленінізму, фізики і хімії [7, 6-6зв]. Потрібно відзначити, що у 1948 - 1949 н.р. основний пріоритет спрямовано на вивчення здобутків російської та радянської науки, не лише в галузях історії і літератури. На противагу “низькопоклонству перед Заходом”, популяризувалися “досягненнях” радянської науки, для чого були введені окремі дисципліни [7, 7-7зв].

Екзаменаційна успішність була доволі високою. Українське відділення факультету мови i літератури ЛДПІ у 1949 р. відзначилося тим, що студенти усіх чотирьох курсів склали екзамени за рік (за винятком трьох студентів). Студенти російського відділу навчалися дещо слабше. Але загалом по факультету 302 студенти склали іспити, 3 них 38 на “відмінно” і 57 на “відмінно” і “добре”. Тож 31 \% студентів факультету мови і літератури отримав позитивні оцінки. Схожий стан справ був на такому ж факультеті. Вищою виявилася успішність на історичному факультеті ЛДПІ: 100 \% студентів зјявилися на іспити, з 135 студентів на “відмінно” і “добре” склали екзамен 66 осіб (майже 50 \%). На фізико-матетичному факультеті з 200 студентів 175 склало екзамени під час сесії, з них на “відмінно” і “добре” - 75 осіб. На природничому факультеті зі 108 студентів склали екзамени 105, з них на “відмінно” і “добре” - 51 особа [7, 83в].

У 1949 р. припинили набирати студентів на вечірнє відділення ЛДПІ, а також і на всі відділення ЛДУІ, де відкрито лише відділення іноземних мов: англійської і французької [7, 12]. У 1950 - 1951 н.р. усі навчальні плани в ЛДПІ були в основному виконані. Невиконаними залишилися декілька годин з нової історії народів Сходу на III курсі історичного факультету. Програмами дисциплін були забезпечені всі факультети. Не було програм лише 3 двох дисциплін: фізіологія людини і тварин, методика літератури. За наказом Міністерства вищої освіти СРСР уведено викладання нової дисципліни: “Основи Сталінського вчення про мови” $[8,10]$.

У дусі часу в ЛДПІ до програм багатьох дисциплін було введено твори Й. Сталіна з питань мовознавства. Перед початком 1950-1951 н.р. лінгвістичні кафедри інституту провели два об'єднані засідання, на яких внесли зміни до програм “відповідно до праць Сталіна”. Створена партбюро і дирекцією інституту комісія на початку жовтня 1950 р. вивчала стан “перебудови” програми на кафедрі української мови. Викладання мов в ЛДПІ двічі перевірялися комісіями Міністерства вищої освіти СРСР і Управління вищої школи Ради Міністрів УРСР. Працівники кафедри марксизму-ленінізму відвідали понад 20 лекцій викладачів мов. Було розкритиковано програму викладання російської мови, яка, на думку членів кафедри марксизмуленінізму, недостатньо відповідала “Сталінським вимогам до вивчення мов”. Загалом лекції викладачів мовних кафедр різні перевіряльники відвідували по 9-11 разів. Усі написані лекції з дисципліни “Основи Сталінського вчення про мови” перед читанням в аудиторіях обговорювалися на кафедрах. У листопаді 1950 р. проведено дводенну конференція, на якій були підбиті підсумки “оволодіння викладацьким складом інституту праць Сталіна з мовознавства”. Участь у конференції взяли всі викладачі інституту [8, 19-20].

Виконуючи рішення сесії Академії наук СРСР і Академії медичних наук СРСР, присвячені розвитку і впровадженню вчення академіка I. Павлова, керуючись наказом Міністерства вищої освіти СРСР від 21.07.1950 р., в ЛДПІ здійснено низку заходів. Зокрема, проведено об'єднані засідання кафедр марксизму-ленінізму, зоології, педагогіки, психології, фізвиховання та інших, під час яких обговорювалися праці академіка. Було організовано дводенну конференцію, присвячену життю і діяльності I. Павлова. Дирекція ЛДПІ запросила з Москви для читання лекцій викладачам учня академіка I. Павлова - доктора біологічних наук Фролова. Перед початком навчального року програми низки дисциплін були змінені з урахуванням рішень сесії Академії наук СРСР. Програми з психології, анатомії, педагогіки значно змінилися, а програму з фізіології людини і тварин цілковито відкинуто і розроблено нову, яка містила ідеї І. Павлова [8, 21-22]. Для вчителів Львова і області викладачі кафедр ЛДПІ прочитали майже 60 лекцій, які поширювали павловські ідеї. Бібліотека інституту значно поповнилася працями І. Павлова [8, 24].

Обов'язком керівництва було відвідування занять. Зокрема, в 1950-1951 н.р. директор інституту і його заступники відвідали 79 занять, декани - 86, завідувачі кафедр - 342. У результаті деякі викладачі були звільнені з роботи, іншим зробили зауваження $[8,11]$. Навчальна робота перевірялась також міністром освіти УРСР Г. Пінчуком, заступником начальника управління педвузів Ф. Усенком, комісією Управління вищої школи при Раді Міністрів УРСР, комісією 


\section{ОСВІТНІЙ ПРОЦЕС У ЛЬВІВСЬКОМУ ДЕРЖАВНОМУ ПЕДАГОГІЧНОМУ ІНСТИТУТІ (1944-1953): ОРГАНІЗАЦЙННТАЗМІСТОВІАСПЕКТИ}

Міністерства вищої освіти СРСР. Протягом 1,5 місяця члени комісій перевіряли документацію кафедр, відвідували лекції, екзамени та заліки $[8,13]$.

Постанови ЦК ВКП(б) і ЦК КП(б)У 3 ідеологічних питань, розпорядження Міністерства вищої освіти СРСР і Міністерства освіти УРСР, звісно ж, уважалися в ЛДПІ керівними документами щодо перебудови програмнонавчальної роботи у напрямі боротьби 3 “ідеологією українського буржуазного націоналізму”. Критикувалися лекції деяких викладачів через те, що вони не були “політично загострені". Наприклад, викладачку кафедри марксизмуленінізму А. Сухову розкритикували за те, що, на думку комісії, “недостатньо глибоко показала зрадницьку роль Тіто і його кліки у Югославії під час Другої світової війни і в післявоєнний період” [8, 10-12].

Студентська самостійна робота. Традиційно значну увагу в радянській вищій школі присвячували самостійній роботі студентів, під якою розуміли як підготовку до семінарських, практичних занять, так і написання курсових робіт, участь у гуртках тощо. У 1944-1945 н.р. значна частина студентів ЛДПІ, особливо першого курсу, не мали навичок самостійної роботи. Тож викладачі змушені були на початку лекційного курсу давати рекомендації студентам щодо конспектування лекцій, роботи над літературою. Працівники кафедри педагогіки С. Смолінський і В. Зиза на всіх факультетах виголосили інструктивні доповіді про графік самостійної роботи студента. У березні 1945 р. навіть проведено методичну конференцію з питань студентської самостійної роботи із таким порядком денним: гігієна і організація розумової праці, бюджет часу студента, праця над книжкою, доповіді кращих студентів про свою самостійну роботу. Вже в другому семестрі кожен студент ЛДПІ змушений був укласти графік власної самостійної роботи $[5,5-53 в]$.

У звіті про роботу ЛДПІ за 1948-1949 н.р., зазначалося, що в закладі була добре організована самостійна робота студентів, яка також була плановою. 3 боку викладацького складу студентам надавалися практичні поради наприклад, як складати графік самостійної роботи і планувати позанавчальну діяльність. Найкращі результати із самостійної роботи показали студенти історичного факультету та українського відділення факультету мов і літератури. Особливе значення для організації самостійної роботи мали курсові роботи, здійснюючи які, на думку керівництва вишу, студенти отримували “навички наукової роботи" [7, 4-4зв].

Відтак акцентувалася увага на посиленні контролю з боку кафедр за самостійною роботою студентів. У 1950-1951 н.р. кафедри ставили завдання викладачам і асистентам, які вели практичні заняття, уважно вивчати самостійну роботу кожного студента. Організовувалися зустрічі першокурсників зі студентамивідмінниками старших курсів, які “ділилися досвідом самостійної роботи над навчальним матеріалом". Кращими щодо організації і контролю за самостійною роботою студентів в цьому навчальному році вважалися кафедри зоології, хімії, деякі викладачі основ марксизмуленінізму [8, 13-14].

У 1953-1954 н.р. викладачі кафедр ЛДПІ читали для студентів лекції на теми методики роботи над книгою, конспектування лекцій і роботи 3 першоджерелами. Деякі кафедри навіть викликали студентів на свої засідання, вимагаючи звіт про самостійну роботу. Окремі викладачі займалися ретельною перевіркою конспектів лекцій студентів начебто “для перевірки правильності і форми записів 3 подальшим аналізом якості конспектування". Великим недоліком в організації самостійної роботи студентів була відсутність в ЛДПІ читального залу на необхідну кількість місць. При кількості 1200 студентів інститут мав читальний зал на 50 місць, що не могло повністю забезпечити їхні потреби [9, 17].

Педагогічна практика. У 1944-1945 н.р. педагогічна практика відбувалася у трьох школах Львова: двох українських (№ 4 і № 31) та одній російській (№ 21). Практику проходили 35 студентів: 13 студентів історичного та мовнолітературного факультетів педагогічного інституту і 17 студентів фізико-математичного та мовно-літературного факультетів учительського інституту. Студенти отримали друковані завдання 3 практики на кожен тиждень. Педагогічна практика проходила за планом, затвердженим ще 1941 р. Наприкінці кожного тижня проводилися підсумкові конференції студентів, де заслуховували звіти про виконану роботу. Відмінні оцінки за практику отримали 19 студентів, добрі - 13, середні - 2. При оцінюванні враховували проведені уроки, конспекти, участь у позашкільних і позакласних заходах. Деякі вчителі не були зацікавлені у практиці і байдуже ставилися до студентів, обмежуючись схематичними загальними вказівками $[5,6-7]$.

Педагогічна практика у першому півріччі 1946-1947 н.р. проводилася на IV-х курсах, у другому півріччі - на III-х курсах ЛДПІ і на II-х курсах ЛДУІ. Вона відбувалася у школах Львова (№ 4, 14, 23, 49 і 16). Для студентів-практикантів 
проводилися відкриті уроки методистів: директора інституту проф. С. Смолінського, викладачів Ю. Редька та І. Михалевського. Деякі школи “не дуже радісно" приймали студентів на практику, особливо у I-й i IV-й чвертях, мотивувавши це тим, що в цей період робота в школі має особливий характер, тому практика студентів заважає проводити освітню діяльність [6, 63в-7]. Члени кафедри педагогіки, особливо В. Зиза, побували на багатьох уроках студентів-практикантів і взяли участь в їх аналізі [6, 73в].

Негативним у проведенні педагогічної практики, було те що їі початок (1 вересня) збігався з початком навчального року у школі. У такий час розклад занять у школі не був стабільним, а деякі школи до 1 вересня ще не завершили ремонт. Загалом педпрактика в 19461947 н.р. була підготовлена і проведена значно краще, ніж в минулі роки, зокрема, вперше проведено психологічну практику і об'єднано психологічний і педагогічний аналізи уроків та інших видів робіт у школі [6, 73в].

У 1948-1949 н.р. студенти проходили педагогічну практику у 14-ти школах Львова. Методисти відвідували уроки. Позитивні оцінки отримали ті студенти, які активно здійснювали позакласну роботу. Усі студенти зјявилися на педагогічну практику. У результаті зі 141 практиканта тільки один отримав незадовільну оцінку [7, 5-5зв].

На 1950-1951 н.р. педагогічна практика других курсів ЛДУІ, третіх і четвертих курсів ЛДПІ проводилася у 17-ти школах Львова, $з$ якими були укладені відповідні угоди. У цьому навчальному році практикувалися 473 студенти, тільки 4 отримали незадовільні оцінки. Значну увагу приділяли оцінюванню проведеної студентамипрактикантами шкільної виховної роботи, яку прирівняно до уроків. У всіх школах студенти організовували виховні заходи: виховну годину, піонерські збори, комсомольські збори. Польову практику студентів природничого факультету проведено відповідно до програми. Основною базою польової практики були колгоспи Бібрського району Львівської області, біоферма Львівського сільськогосподарського інституту та ботанічний сад ЛДПІ [8, 15-18].

Відзначимо, що під час практики студентів Львівського ДПІ у 1950 р. виявилося, що деякі з них погано знали підручники і програми середньої школи, не вміли складати конспекти та працювати з книжками. Однією з головних залишалася мовна проблема. Практиканти не знали досконало ні російської, ні української. Занадто помітним було й хвилювання перед аудиторією. У багатьох тремтіли руки. Молодих людей не навчили триматися перед аудиторією. Одна зі львівських студенток через подібне хвилювання навіть не змогла провести урок [13, 295].

Педагогічну практику проходили у вересні та жовтні 1953 р. студенти четвертих курсів факультетів ЛДПІ - 210 осіб: 104 студенти фізикоматематичного і біологічного факультету, 103 студенти історико-філологічного факультету. До кожної групи закріплювався керівник-методист. Найкращими керівниками-методистами керівництво ЛДПІ вважало таких викладачів: Т. Марусенко, Ф. Ткач, 3. Калініна (історико-філологічний факультет), О. Вагилевич, І. Землянський, Л. Романова (фізико-математичний і біологічний факультет) [9, 18-19]. Під час практики студенти проводили екскурсії на підприємства Львова, наприклад, на фабрику музичних інструментів, маслозавод, завод автонавантажувач, вагоноремонтний завод, трамвайно-тролейбусне управління [9, 23]. Однак траплялося, що не всі студенти добре володіли методикою проведення уроків і знанням програмного матеріалу [9, 24].

Виховання студентів. Першорядним напрямом виховної роботи в ЛДПІ було “ідейнополітичне виховання”. Після завершення Другої світової війни серед студентів активно проводилася пропаганда про велич Червоної Армії та їі керівника Сталіна. На таку тематику в інституті виголосили 32 доповіді. Кожного дня впродовж 1944-1945 н.р. на великій перерві проводили “десятихвилинку”, де інформували студентів про події на фронтах Другої світової війни. Проводились тематичні виставки, присвячені різним подіям радянської історії $[5,11]$.

“Політико-виховна робота” проводилась в академічних групах на факультетських і на загальних інститутських зборах студентів, а також шляхом окремих спеціальних заходів. Роботу в групах проводили “прикріплені” викладачі “ідейні керівники”. У групах опрацьовували питання поточної політики, поведінки та дисципліни студентів, методики самостійних занять, зачитувалися накази директора, а також вивчалися керівні матеріали компартії i Міністерства освіти. 26 і 27 травня 1947 р. відбулася конференція, на якій підбито підсумки щодо вивчення студентами біографій Леніна та Сталіна. У травні того ж року в інституті був проведений диспут на тему “Моральне обличчя молодої людини нашої епохи” [6, 12-13].

У 1950-1951 н.р. до академічних груп за вказівкою партійного бюро ЛДПІ були прикріплені викладачі-комуністи, які складали плани політиковиховної роботи у групах, щотижня проводили 


\section{ОСВІТНІЙ ПРОЦЕС У ЛЬВІВСЬКОМУ ДЕРЖАВНОМУ ПЕДАГОГІЧНОМУ ІНСТИТУТІ (1944-1953): ОРГАНІЗАЦЙНІ ТА ЗМІСТОВІ АСПЕКТИ}

політзаняття та політінформації. Вони постійно вивчали настрої та побут студентів, давали завдання студентам проводити політичнопросвітницьку роботу під час канікул [8, 28-29]. У педінституті систематично читали лекції на політичні теми, наприклад, “Українські буржуазні націоналісти - вороги українського народу, агенти англо-американського імперіалізму”, “Сталін і колгоспне селянство” (І. Росохін), “Лев Толстой - дзеркало російської революції” (ст. викладач А. Позняков). Такі лекції відбувалися кожної суботи. Частина студентів виступали з іделогічними лекціями в установах, підприємствах і закладах освіти міста [8, 31-32].

Ідейно-виховна робота в ЛДПІ $1953 \mathrm{p}$. проводилася шляхом лекційної роботи зі студентами та викладачами, семінарських занять, проведення політінформації для студентів, науково-теоретичних конференцій, організації екскурсій та зустрічей 3 відомими людьми Львівської області та УРСР. Студенти побували на 14 екскурсіях у музеях Львівщини. В інституті було впроваджено шість додаткових курсів 3 вивчення історії і теорії КПРС, політекономіки проведено 13 тематичних вечорів, присвячених радянським письменникам і вченим [9, 38, 40-42].

Висновки. Отже, з жовтня 1944 р. заняття велися на чотирьох факультетах ЛДПІ: мовнолітературному, історичному, фізико-математичному та природничому. Графіки навчального процесу, починаючи з 1944-1945 н.р. переважно не виконувалися. Значною проблемою у 1940-х рр. в роботі всіх факультетів була повна або часткова відсутність нових програм навчальних дисциплін. У 1944-1947 рр. спостерігалися проблеми у забезпеченні підручниками, особливо для гуманітарних дисциплін. На зміст освітньої праці мали вплив ідеологічні кампанії, які відбувалися в СРСР. У 1947-1948 рр. деяких викладачів інституту критикували за помилки під час викладання історії та літератури, схиляння перед західною наукою. 3 1949-1950 рр. великого значення у навчальному процесі надавали “мовознавчим працям” Й. Сталіна. 31950 р. зміст програм перебудовувався через ідеологічну популяризацію теорії І. Павлова. В умовах тотального контролю над життям студентства, закономірною була увага керівництва і педагогів ЛДПІ до самостійної роботи здобувачів освіти. Її прагнули контролювати, унормувати за допомогою графіків та чітких методик опрацювання літератури, конспектування лекцій тощо. Педагогічна практика відбувалася переважно у школах Львова. 3 кінця 1940-х рр. від студентів вимагали не лише якісного проведення уроків, але і виховної роботи з учнями. Попри часто високу успішність студентів, траплялися випадки їх методичної і психологічної неготовності до роботи в школі. Виховна діяльність ЛДПІ зосереджувалася переважно в політико-ідеологічній площині й спрямовувалася на комуністичну індоктринацію студентів. Вона охоплювала різноманітні форми - від звичайних лекцій до екскурсій і зустрічей з відомим радянськими діячами. Задля ідеологічного впливу і водночас контролю (навіть стеження) за студентством 31950 р. до академічних груп у ЛДПІ прикріплювалися викладачі-комуністи, які складали плани “політико-виховної роботи” у групах, щотижня проводили політзаняття та політінформації, постійно вивчали настрої та побут студентів. Перспективним напрямом досліджень $\epsilon$ зјясування змін в освітньому процесі ЛДПІ у роки “відлиги".

\section{ЛІТЕРАТУРА}

1. Вища школа УРСР за 50 років Радянської влади: у 2-х частинах. Ч. 1. Київ, 1967. 396 с.

2. Глузман А. Тенденции развития университетского педагогического образования в Украине. Киев, 1997. $479 \mathrm{c}$.

3. Головко Н. Восстановление и развитие системи высшего и среднего педагогического образования Украинской ССР (1943-1950 гг.). Киев, 1987. 156 с.

4. Державний архів Львівської області (далі ДАЛО). Ф. Р-7: Львівський державний педагогічний іститут. Оп. 1. Спр. 5. - 52 арк.

5. ДАЛО. Ф. Р-7. Оп. 1. Спр. 31. - 31 арк.

6. ДАЛО. Ф. Р-7. ОП. 1. Спр. 40. - 41 арк.

7. ДАЛО. Ф. Р-7. ОП. 1. Спр. 51. - 43 арк.

8. ДАЛО. Ф. Р-7. Оп. 1. Спр. 65. - 135 арк.

9. ДАЛО. Ф. Р-7. Оп. 1. Спр. 109. - 97 арк.

10.Кобзарева Т. Развитие высшего заочного педагогического образования в Украинской ССР (1928-1975 гг.). Киев, 1977. 122 с.

11. Кошарний I. У сузір'ї соціалістичної культури. Культурне будівництво у возз'єднаних областях Української РСР (1939 - 1958 рр.). Львів: Вища школа, 1975. 238 с.

12.Культурне життя в Україні. Західні землі. Документи і матеріали. Т. 1: 1939-1953. Київ: "Наукова думка", 1995. 750 с.

13. Лук'яненко О. “Найближчі друзі партіі”: колективи педагогічних вишів України в образах щодення 1920-х - першої половини 1960-х років: Монографія. Полтава: Видавництво “Сімон”, $2019.658 \mathrm{c}$.

14. Майборода В. Вища педагогічна освіта в Україні: історія, досвід, уроки (1917-1985 рр.). Київ: Либідь, 1992. 195 с. 
15.Прокопів Л. Навчально-виховна робота 3 обдарованою молоддю у вищих педагогічних закладах України (друга половина ХХ ст.). ІваноФранківськ: Плай, 2005. 256 с.

16. Сергійчук О. Вища школа України в умовах лібералізації суспільного життя 1953-1964 рр. Автореф. дис... канд. істор. наук. Київ, 2002. 17 с.

\section{REFERENCES}

1. Vyshcha shkola URSR. Vyshcha shkola URSR za 50 rokiv Radianskoi vlady: u 2-kh chastynakh. Ch. 1. (1967). [Higher school of the USSR for 50 years of Soviet power: in 2 parts. Part 1]. Kyiv, 396 p. [in Ukrainian].

2. Gluzman, A. (1997). Tendentsyi razvityia universitetskogo pedagogicheskogo obrazovanyia v Ukraine [Trends in the development of university pedagogical education in Ukraine]. Kiev, 479 p. [in Russian].

3. Holovko, N. (1987). Vosstanovlenye i razvitie sistemy vysshego i srednego pedagogicheskogo obrazovanyia Ukrainskoi SSR (1943-1950 gg.) [Restoration and development of the system of higher and secondary pedagogical education of the Ukrainian SSR (1943-1950)]. Kiev, 156 p. [in Russian].

4. Derzhavnyi arkhiv Lvivskoi oblasti (DALO). Fond. R-7: Lvivskyi derzhavnyi pedahohichnyi istytut. Op. 1. Spr. 5. - 52 ark. [State Archives of Lviv Region (SALR). Found R-7: Lviv State Pedagogical Institute. Description 1. Cases 5. - 52 p.]. [in Ukrainian].

5. DALO. F. R-7. Op. 1. Spr. 31. - 31 ark. [SALR. F. R-7. D. 1. C. 31. - 31 p.]. [in Ukrainian].

6. DALO. F. R-7. Op. 1. Spr. 40. -41 ark. [SALR. F. R-7. D. 1. C. 40. - 41 p.]. [in Russian]. 7. DALO. F. R-7. Op. 1. Spr. 51. -43 ark. [SALR. F. R-7. D. 1. C. 51. - 43 p.]. [in Russian]. 8. DALO. F. R-7. Op. 1. Spr. 65. - 135 ark. [SALR. F. R-7. D. 1. C. 65. - 135 p.]. [in Russian].

9. DALO. F. R-7. Op. 1. Spr. 109. - 97 ark. [SALR. F. R-7. D. 1. C. 109. - 97 p.]. [in Russian] 10.Kobzareva, T. (1977). Razvitie vysshego zaochnogo pedagogicheskogo obrazovanyia $\mathrm{v}$ Ukrainskoi SSR (1928-1975 gg.) [Development of higher correspondence pedagogical education in the Ukrainian SSR (1928-1975)]. Kiev, 122 p. [in Russian].

11. Kosharnyi, I. (1975). U suziri sotsialistychnoi kultury. Kulturne budivnytstvo u vozziednanykh oblastiakh Ukrainskoi RSR (1939 - 1958 rr.) [In the constellation of socialist culture. Cultural construction in the reunited regions of the Ukrainian SSR (19391958)]. Lviv, 238 p. [in Ukrainian].

12. Kulturne zhyttia v Ukraini. (1995). Kulturne zhyttia v Ukraini. Zakhidni zemli. Dokumenty i materialy [Cultural life in Ukraine. Western lands. Documents and materials]. T. 1: 1939-1953. Kyiv, 750 p. [in Ukrainian].

13.Lukianenko, O. (2019). "Naiblyzhchi druzi partii": kolektyvy pedahohichnykh vyshiv Ukrainy v obrazakh shchodennia 1920-kh - pershoi polovyny 1960-kh rokiv ["The closest friends of the party": teams of pedagogical institutes of Ukraine in the images of everyday life of the 1920 s - first half of the 1960s]. Poltava, 658 p. [in Ukrainian].

14. Maiboroda, V. (1992). Vyshcha pedahohichna osvita v Ukraini: istoriia, dosvid, uroky (1917-1985 rr.) [Higher pedagogical education in Ukraine: history, experience, lessons (1917-1985)]. Kyiv, 195 p. [in Ukrainian].

15.Prokopiv, L. (2005). Navchalno-vykhovna robota $\mathrm{z}$ obdarovanoiu moloddiu u vyshchykh pedahohichnykh zakladakh Ukrainy (druha polovyna XX st.) [Educational work with gifted youth in higher pedagogical institutions of Ukraine (second half of the XX century)]. Ivano-Frankivsk, 256 p. [in Ukrainian].

16. Serhiichuk, O. (2002). Vyshcha shkola Ukrainy v umovakh liberalizatsii suspilnoho zhyttia 1953-1964 rr. [Higher School of Ukraine in the conditions of liberalization of public life 1953-1964]. Extended abstract of candidate's thesis. Kyiv, 17 p. [in Ukrainian].

Стаття надійшла до редакції 21.09.2021

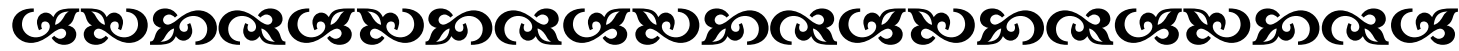

“В силу самої своєї природи наука і логічне мислення ніколи не здатні судити, що можливо, а що - ні. Їх єдине призначення - пояснювати те, що було забіксовано досвідом і спостереженнями".

Рудольб Шайиер австрійський вчений, боілособб

"Ніхто не зможе побудувати для Вас міст, на яқому Ви повинні перетнути потік життя, ніхто, қрім Вас самих."

Фрідріх Hiщuе німеиький білособ

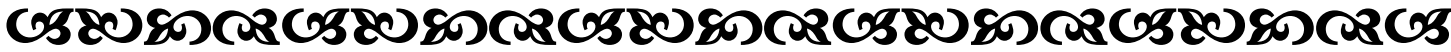

